Part of Journal of Research of the National Bureau of Standards, Volume 25, July 1940

\title{
CORROSION OF METALS USED IN AIRCRAFT
}

\author{
By Willard Mutchler
}

\section{ABSTRACT}

Investigations of the corrosion of metals used in aircraft have been in progress continuously at the National Bureau of Standards since 1925. The projects have been sponsored by the National Advisory Committee for Aeronautics, the Army Air Corps, and the Bureau of Aeronautics of the Navy Department. The present paper reviews the work that has been done, summarizes the more important results, and lists the publications in which fuller details appear.

\section{CONTENTS}

I. Introduction

II. Procedure

III. Methods of exposure

IV. Summary of tests and results

1. Corrosion of aluminum alloys

2. Protective coatings on aluminum alloys

3. Corrosion of magnesium alloys

4. Protective coatings on magnesium alloys $\ldots \ldots$

5. Corrosion of stainless steels

6. Corrosion of rivets and welds

V. 7. Corrosion of dissimilar metals in contact

\section{INTRODUCTION}

When aluminum-rich alloys of the duralumin type were first used in aircraft construction, there occurred numerous instances of extremely rapid corrosion, accompanied by embrittlement. An investigation was begun at this Bureau (1) to develop methods for producing and determining the causes of this corrosion-embrittlement, and (2) to evolve methods for its elimination or prevention. Early studies of such variables as chemical composition, heat treatment, and aging of the alloys were successful in these two respects. The efficiencies of various oxide coatings, particularly in combination with organic or paint coatings, were next studied. Currently, the corrosion of aluminum alloys when in contact with each other, or with dissimilar metals, or when joined by rivets and welds, is being investigated.

Studies of the corrosion of magnesium-rich alloys, with and without protective coatings, were begun in 1929 with the object of developing more corrosion-resistant alloys and better surface coatings. An investigation of the corrosion of stainless steels was started in 1938 to determine the effect of the addition of such elements as columbium, titanium, and molybdenum to steels of the 18-chromium 8-nickel type and to determine the behavior of shot welds on such steels. 
Approximately 25,000 specimens of 60 alloys have been tested. The alloys, their nominal chemical compositions, and condition of fabrication are listed in tables 1 to 3 , inclusive. The greatest number of specimens were in sheet form, usually from 0.040 to 0.064 inch thick.

TABLE 1.-Summary of data on the aluminum alloys included in the investigation

\begin{tabular}{|c|c|c|c|c|c|c|c|c|c|c|}
\hline \multirow{2}{*}{ Alloy designation } & \multirow{2}{*}{$\begin{array}{l}\text { Fabri- } \\
\text { cation }{ }^{\mathrm{e}}\end{array}$} & \multirow{2}{*}{ Exposure $\mathrm{d}$} & \multicolumn{6}{|c|}{ Nominal chemical composition } & \multirow{2}{*}{$\begin{array}{l}\text { Rela- } \\
\text { tive } \\
\text { corro- } \\
\text { sion } \\
\text { resist- } \\
\text { ance }\end{array}$} & \multirow{2}{*}{$\begin{array}{l}\text { Literature } \\
\text { reference }^{f}\end{array}$} \\
\hline & & & $\mathrm{Mg}$ & $\mathrm{Cu}$ & $\mathrm{Mn}$ & $\mathrm{Fe}$ & $\mathrm{Si}$ & Other elements & & \\
\hline $\begin{array}{l}14 S \\
25 S_{-}\end{array}$ & $f p_{-}$ & $\begin{array}{l}W, T^{T}, W_{-} \\
I,\end{array}$ & $\begin{array}{c}\% \\
0.4 \\
.0\end{array}$ & $\begin{array}{l}\% \\
4.4 \\
4.5\end{array}$ & $\begin{array}{c}\% \\
0.8 \\
.8\end{array}$ & $\begin{array}{r}\% \\
0.5 \\
.4\end{array}$ & $\begin{array}{r}\% \\
0.8 \\
.8\end{array}$ & & $\underset{E}{E}$ & $\begin{array}{l}{[18]} \\
{[5 \mathrm{II}, 5 \mathrm{III}}\end{array}$ \\
\hline $\begin{array}{l}24 S \mathrm{a} \\
I-2 \mathrm{~b} \\
I-1 \mathrm{~b} \\
17 S \mathrm{~S}\end{array}$ & $\begin{array}{l}s, e x \\
s-. \\
s- \\
s, r\end{array}$ & $\begin{array}{l}I, S, W, T \\
I, W \\
I, W \\
I, S, W, T\end{array}$ & $\begin{array}{r}1.5 \\
0.5 \\
.5 \\
.5\end{array}$ & $\begin{array}{l}4.4 \\
4.0 \\
4.0 \\
4.0\end{array}$ & $\begin{array}{l}.5 \\
.5 \\
.5 \\
.5\end{array}$ & $\begin{array}{l}.2 \\
.07 \\
.2 \\
.3\end{array}$ & $\begin{array}{l}.1 \\
.08 \\
.2 \\
.3\end{array}$ & & $\begin{array}{c}D, A^{\mathrm{a}} \\
D \\
D \\
D, A^{\mathrm{a}}\end{array}$ & $\begin{array}{l}5 \mathrm{~V}, 10,17] \\
{[17,18]} \\
{[5 \mathrm{II}, 5 \mathrm{~V}, 10]} \\
{[5 \mathrm{II}, 5 \mathrm{~V}, 10]} \\
{[1 \text { to } 11,15}\end{array}$ \\
\hline $\begin{array}{l}\text { Baush dura } \\
\text { Carbium }\end{array}$ & & $I, S, W_{-}$ & $\begin{array}{l}.5 \\
.5\end{array}$ & $\begin{array}{l}4.0 \\
4.0\end{array}$ & $\begin{array}{l}.5 \\
.5\end{array}$ & $\begin{array}{l}.3 \\
.3\end{array}$ & $\begin{array}{l}.3 \\
.3\end{array}$ & $\begin{array}{l}\text { Cr. } 0.15 \\
\text { C } 0.01\end{array}$ & $\begin{array}{l}D \\
D\end{array}$ & {$[5,10]$} \\
\hline & & $I, W$ & .6 & 3.8 & .5 & 1. 1 & .2 & & $D$ & {$[5 \mathrm{II}, 5 \mathrm{~V}, 10]$} \\
\hline$E$ & & $\vec{I}, W$ & .5 & 3.7 & .02 & 0.3 & .3 & -- & $D$ & $5 \mathrm{II}, 5 \mathrm{~V}, 10$ \\
\hline 58 & $s_{-r}$ & $I, W-\ldots$ & .6 & 3.1 & .5 & .5 & .2 & $-\cdots$ & $D$ & {$[5 \mathrm{II}, 5 \mathrm{~V}, 10]$} \\
\hline $\begin{array}{l}\text { Nicralumin (Hy- } \\
\text { blum). }\end{array}$ & $s_{-1}$ & $I, S, W$ & .5 & 0.4 & .22 & .5 & .3 & $\begin{array}{c}\mathrm{Ni} 1.0, \mathrm{Mo} 0.1, \\
\mathrm{Zn} 0.2, \mathrm{~W}\end{array}$ & ${ }^{D}$ & $[17], h v, 10]$ \\
\hline Major Metal. & $s, b_{\ldots} \ldots$ & $I, W, T_{-}$ & .3 & 1.4 & .1 & .5 & .3 & $\begin{array}{l}\text { Ni } 0.9, \mathrm{Ag} 0.5, \\
\mathrm{Zn} 0.2, \mathrm{~Pb} \\
0.1, \mathrm{Cr}<0.05\end{array}$ & $D$ & \\
\hline im $R R 50$ & $f b, c b$ & $\underset{S}{S}$ & .5 & 2. 0 & .02 & 1.2 & 1. 0 & $\mathrm{Ni} 1.2, \mathrm{Ti}<0.2$ & $D$ & \\
\hline R5s & $f b, c b_{\ldots}$ & $S$ & 1.6 & 2. 2 & .01 & 1. 6 & 1.3 & Ni $1.1, T$ & $D$ & \\
\hline Aeral........ & s...... & $I, S, W$ & 0.8 & 4.0 & .3 & 0.3 & 0.4 & $\mathrm{Cd} 2.0$ & $D$ & [17] \\
\hline$Y$ alloy & $s_{-}$ & $I$ & 1.6 & 4.0 & $<.01$ & .3 & .2 & Ni 2.0. & $D$ & [5 II] \\
\hline $51 \mathrm{~S}$ & $s_{-}$ & $I, S, W$ & 0.6 & 0.05 & .01 & .3 & 1.0 & & $C$ & [5 II, 5 II \\
\hline $\begin{array}{l}X A 51 S \\
4 S\end{array}$ & $s_{-}$ & $\stackrel{S}{S}, W$ & $\begin{array}{r}.6 \\
1.0\end{array}$ & $\begin{array}{l}.05 \\
.1\end{array}$ & 1.01 & $\begin{array}{l}.3 \\
.4\end{array}$ & $\begin{array}{l}1.0 \\
0.2\end{array}$ & $\mathrm{Cr} 0.25$ & $\underset{B}{C}$ & {$[17]$} \\
\hline $\begin{array}{l}53 \mathrm{~S} \\
\mathrm{X} 52 \mathrm{~S} \\
52 \mathrm{~S} \\
\mathrm{X} B 52 \mathrm{~S} \\
\mathrm{AM} \mathrm{M} 5 \mathrm{~S} \\
56 \mathrm{~S} \\
\text { Inalium }\end{array}$ & $\begin{array}{l}s, r, e p \\
s_{-} \\
s- \\
s, r_{-} \\
r- \\
s, r_{-} \\
s_{-}\end{array}$ & $\begin{array}{l}S, W, T \\
S, W \\
S, W, T \\
S, W \\
W, T \\
S, W \\
I, S, W_{-.}\end{array}$ & \begin{tabular}{|l|}
1.2 \\
1.25 \\
2.5 \\
3.5 \\
4.5 \\
6.0 \\
0.8
\end{tabular} & $\begin{array}{l}.02 \\
.02 \\
.02 \\
.02 \\
.01 \\
.02 \\
.0\end{array}$ & $\begin{array}{l}0.0 \\
.0 \\
.0 \\
.0 \\
.0 \\
.0 \\
.0\end{array}$ & $\begin{array}{l}.2 \\
4 \\
.1 \\
.2 \\
.1 \\
.1 \\
.2\end{array}$ & $\begin{array}{l}.7 \\
.2 \\
.1 \\
.1 \\
.07 \\
.06 \\
.4\end{array}$ & $\begin{array}{l}\text { Cr } 0.25 \\
\text { Cr } 0.2 \\
\text { Cr } 0.25 \\
\text { Cr } 0.25 \\
\text { Cd } 2.0 \\
\end{array}$ & $\begin{array}{l}B \\
A \\
A \\
A \\
B \\
B \\
B\end{array}$ & $\begin{array}{l}{[18]} \\
{[17]} \\
{[17,18]} \\
{[17]} \\
117 \\
{[17]}\end{array}$ \\
\hline $\begin{array}{l}\text { Al-Be No. } 1 \text { b } \\
\text { Al-Be No. } 2 \text { b. }\end{array}$ & $\begin{array}{l}s_{-.} \\
s_{-\ldots}\end{array}$ & $\begin{array}{l}I_{-} \\
I_{-}\end{array}$ & $\begin{array}{l}1.2 \\
0.0\end{array}$ & $\begin{array}{l}.05 \\
.05\end{array}$ & $\begin{array}{l}.0 \\
.0\end{array}$ & .1 & .1 & $\begin{array}{l}\mathrm{Be} 0.8 \\
\mathrm{Be} 0.4\end{array}$ & $\stackrel{C}{C}$ & $\left.\begin{array}{ll}{[5} & \mathrm{II} \\
{[5} & \mathrm{II}\end{array}\right]$ \\
\hline
\end{tabular}

a Alloys also exposed with high-purity aluminum (Alclad) surface coatings, which afforded excellent protection against corrosion.

b Alloys prepared especially for this investigation. The duralumins were $I-1$, controlled impurities; $I-2$, high-purity ingredients; $58 B$, low copper; $63 . A$ high iron.

$\circ$, sheet; $p$, plate; $r$, rivet; $b$, bar; $c$, cast; $e$, extruded; $f$, forged.

d $I$, intermittent immersion; $S$, salt spray; $W$, weather; $T$, tidewater.

- The ratings are approximations only, based on the assumption that the alloy was exposed in its most resistant form to severely corrosive saline conditions. They are applicable to the aluminum alloys only. $A$ is the highest rating.

$f$ Further details are reported in cited references at end of this paper. 
TABLE 2.- Summary of data on the magnesium alloys included in the investigation

\begin{tabular}{|c|c|c|c|c|c|c|c|}
\hline \multirow{2}{*}{ Alloy designation } & \multirow{2}{*}{$\begin{array}{l}\text { Fabri- } \\
\text { cation } 1\end{array}$} & \multirow{2}{*}{ Exposure ${ }^{2}$} & \multicolumn{3}{|c|}{$\begin{array}{l}\text { Nominal chemical compo- } \\
\text { sition }\end{array}$} & \multirow{2}{*}{$\begin{array}{c}\text { Rela- } \\
\text { tive } \\
\text { corro- } \\
\text { sion } \\
\text { resist- } \\
\text { ance } 3\end{array}$} & \multirow{2}{*}{$\begin{array}{l}\text { Litera- } \\
\text { ture } \\
\text { ref- } \\
\text { erence }\end{array}$} \\
\hline & & & $\mathrm{Al}$ & Mn & Other elements & & \\
\hline$A M S S$, Dowmetal $M$, Elek- & $s, p$ & $W, T, S$ & $\%$ & $\begin{array}{r}\% \\
1.5\end{array}$ & $\%$ & A & {$[17,18]$} \\
\hline$\stackrel{\text { tron }}{M}$ & & & 0.4 & 0.01 & & $C$ & [11] \\
\hline$M M(A M 53 S)$, Dowmetal $F$ & $s, c p, e b$ & $W, S$ & 4.0 & .3 & & $C$ & {$[11,17]$} \\
\hline $\begin{array}{l}M A \\
\text { Dowmetal } E_{1}\end{array}$ & $s_{-\ldots}$ & $\begin{array}{l}W \\
W \\
W\end{array}$ & $\begin{array}{l}3.9 \\
6.0\end{array}$ & $\begin{array}{l}.01 \\
.3\end{array}$ & & $\begin{array}{l}C \\
D\end{array}$ & {$[11]$} \\
\hline $\begin{array}{l}A M 241(A M 7.4), \text { Dowmetal } \\
A .\end{array}$ & $c p, c b$ & & 7.4 & .3 & & $D$ & \\
\hline$A M 240$ & $c p$ & $W, \underset{S}{S}$ & 9.0 & .1 & & $D$ & {$[17]$} \\
\hline$\underset{J .}{A Z M}(A M 5 \gamma)$, Dowmetal & $e b, h p$ & $W, S_{\ldots}$ & 6.5 & .2 & $\mathrm{Zn} 0.75$ & $B$ & {$[17]$} \\
\hline Dowmetal $H$, Elektron $A Z G$ - & $c b, e p$ & $\underset{W}{W}, T, S, I$. & 6.5 & .2 & $\operatorname{Zn} 3.0$ & ${ }_{B}^{B}$ & {$[17,18]$} \\
\hline tal “ $S$ "'-............. & & $W, \overline{\mathrm{S}}$ & & & $\begin{array}{l}\mathrm{Zn} 3.4, \mathrm{Sn} 4.6 \ldots \\
\mathrm{Zn} 1.0, \mathrm{Cd} 3.0_{-}\end{array}$ & $\stackrel{B}{E}$ & {$[17$} \\
\hline$A M 61 S$ & $f p, p_{-}$ & $W$ & & 1.0 & Sn 6.5 & $A$ & 17 \\
\hline $\begin{array}{l}\text { AM65 } \\
\text { Dowm }\end{array}$ & $f p_{n} \ldots$ & $W, S_{\ldots} \ldots$ & 4. 0 & 1.0 & Sn $5.0 \ldots$ & $A$ & 17 \\
\hline Dowmeta & $c p_{-.}$ & $W_{-}$ & 2.0 & 0.1 & $\mathrm{Cu} 4.0, \mathrm{Cd} 1.7$ & $E$ & (11] \\
\hline
\end{tabular}

$1 s$, sheet; $p$, plate; $b$, bar; $c$, cast; $e$, extruded; $f$, forged; $h$, hot-pressed; products rolled, if not otherwise indicated.

$2 I$, intermittent immersion; $S$, salt spray; $W$, weather; $T$, tidewater.

3 The ratings are approximations, with $A$ the highest rating. They are applicable to the magnesium alloys only, and are based on behavior under saline conditions of exposure.

1 Further details are reported in the literature references at end of this paper.

TABLE 3.-Summary of data on the stainless steels and nickel alloys included in the investigation

\begin{tabular}{|c|c|c|c|c|c|c|c|c|c|}
\hline \multirow{2}{*}{ Alloy designation 1} & \multicolumn{8}{|c|}{ Nominal chemical composition } & \multirow{2}{*}{$\begin{array}{c}\text { Rela- } \\
\text { tive } \\
\text { corro- } \\
\text { sion } \\
\text { resist- } \\
\text { ance }\end{array}$} \\
\hline & $\mathrm{Cr}$ & $\mathrm{Ni}$ & $\mathrm{C}$ & $\mathrm{Mn}$ & $\mathrm{S}$ & $\mathrm{P}$ & $\mathrm{Si}$ & Other elements & \\
\hline Stainless steels: & $\%$ & $\%$ & $\%$ & $\%$ & $\%$ & $\%$ & $\%$ & & \\
\hline Type 302 & 17.6 & 7.5 & 0.10 & 0.5 & 0.01 & 0.01 & 0.4 & & $B$ \\
\hline Type 304 & 18.4 & 8.3 & .08 & .4 & .01 & .01 & .4 & & $B$ \\
\hline Type 306 & 19.5 & 9.5 & .09 & .4 & .01 & .02 & 3 & & $B$ \\
\hline Туре 316 & 17.8 & 10.7 & .05 & 1.3 & .01 & .01 & .3 & Mo 2.7 & $A$ \\
\hline Type & 17.9 & 12.4 & .07 & 1.5 & .01 & .01 & .3 & Mo 3.7 - & $A$ \\
\hline Type 347 & 18.3 & 9.9 & .08 & 0.4 & .01 & .01 & .0 & $\mathrm{Cb} 0.5$ & $B$ \\
\hline Do & 18.4 & 8.6 & .08 & .4 & .02 & .01 & .4 & $\mathrm{Cb} 0.8$ & $B$ \\
\hline Type 321 & 17. 6 & 9.1 & .07 & .4 & .01 & .01 & .5 & Ti 0.5 & $B$ \\
\hline $16-1 \ldots$ & 17.7 & 1. 6 & .08 & .7 & .02 & .01 & .5 & & $C$ \\
\hline Nickel alloys: & & & & & & & & & \\
\hline $\begin{array}{l}\text { Nickel ...... } \\
\text { Monel }\end{array}$ & -- & 99.4 & .1 & .2 & .005 & & .05 & Cu 0.1 , Fe $0.15 \ldots$ & $B$ \\
\hline Inconel...... & 13.5 & 78.5 & .25 & .9 & & 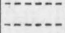 & 0.6 & Cu 0.25, Fe 6.0 & $A$ \\
\hline
\end{tabular}

1 The alloys were in sheet form and were exposed to weather and tidewater at Hampton Roads, Va. Literature reference [18] contains results of the tests.

2 The highest rating is $A$, and ratings are applicable only to alloys given in this table.

\section{PROCEDURE}

Tensile bars, strips, or large panels were exposed to accelerated tests in the laboratory, to the weather, or to tidewater corrosive conditions, and corroded specimens from each set were removed at progressive intervals for test. Diagrams of typical specimens are shown in figure 1. Each corroded specimen was photographed and then broken in a tensile test. Differences in the tensile properties from those of uncorroded specimens (stored in a dry atmosphere in sealed containers in 
the laboratory) served as an indirect measure of the corrosion. Microscopic examinations were made subsequently of metallographic sections of the tested specimens to determine the nature of the corrosive attack, and measurements were made of the depth and extent of its penetration. Permanent records of the corrosive attack were made by a special method developed for the purpose [15] ${ }^{1}$, at 50 to 250 magnifications on photostat paper negatives, at a rate of approximately 650 per day.

\section{METHODS OF EXPOSURE}

The majority of the accelerated laboratory corrosion tests were conducted by either the intermittent-immersion or the salt-spray methods (fig. 2). In the intermittent-immersion tests, specimens were immersed in the corroding medium for approximately 1 minute and suspended in air for 14 minutes, the cycle being repeated continuously. The corroding medium usually consisted of a mixture of 9 parts of a normal sodium chloride solution and 1 part of commercial hydrogen peroxide, although other reagents were used. An apparatus was designed to permit flexural stressing of the sheet specimens in order to study the effect of the combined action of stress and corrosion. The majority of the salt-spray tests were conducted in a finely atomized spray or mist of a 20-percent sodium-chloride solution.

The weather-exposure localities (fig. 3) were Washington, D. C., Hampton Roads, Va., and Coco Solo, C. Z. The first two localities were selected as representative of temperate climate, with and without a saline atmosphere, whereas the third combined a tropical climate with marine conditions. At Hampton Roads, in 1938, tidewater exposure racks were installed to permit immersion of the panels in salt water twice each day.

\section{SUMMARY OF TESTS AND RESULTS}

\section{CORROSION OF ALUMINUM ALLOYS}

Early in the investigation, corrosion in alloys of the duralumin type was found to be of two distinct types (fig. 4): (a) the "pitting" type, in which surface pits are formed that bear no evident relation to the microstructure of the metal, analogous to the rusting of ferrous metals, and (b) the intercrystalline type, of which only slight evidence may be seen on the surface, but which penetrates into the interior, largely between the grain boundaries.

Intercrystalline attack was shown to be responsible for the serious embrittlement of duralumin. It was found to be associated with certain microstructural conditions that resulted from incorrect heat treatment, namely, those in which particles of the constituent $\mathrm{CuAl}_{2}$ were precipitated along the grain boundaries and quite abundantly within the grains. The rate of cooling during the quenching that followed the preliminary "solution" heat treatment was found to be a determining factor. After a solution heat treatment at $500^{\circ} \mathrm{C}$, it had been the practice to quench duralumin in warm water to minimize distortion. It was shown (fig. 4, f) that quenching in cold water, preferably below $25^{\circ} \mathrm{C}$, resulted in retention of the $\mathrm{CuAl}_{2}$ particles

\footnotetext{
1 Figures in brackets indicate the literature references at the end of this paper.
} 


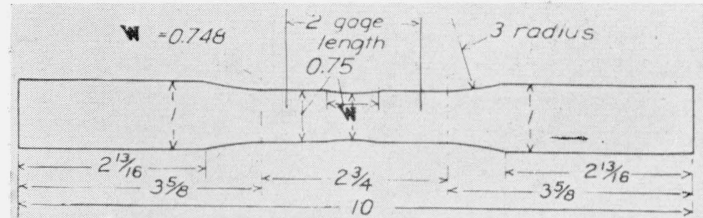

A

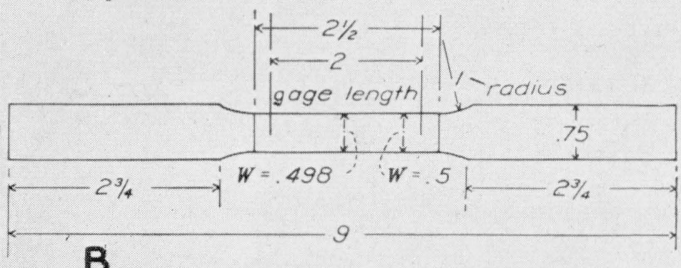

B

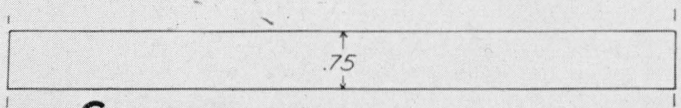

C

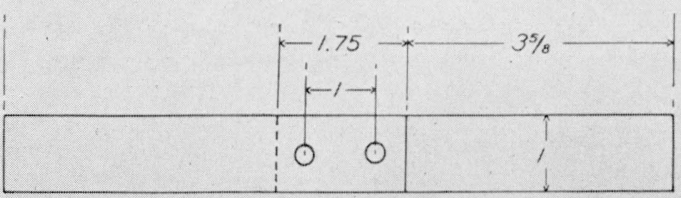

D

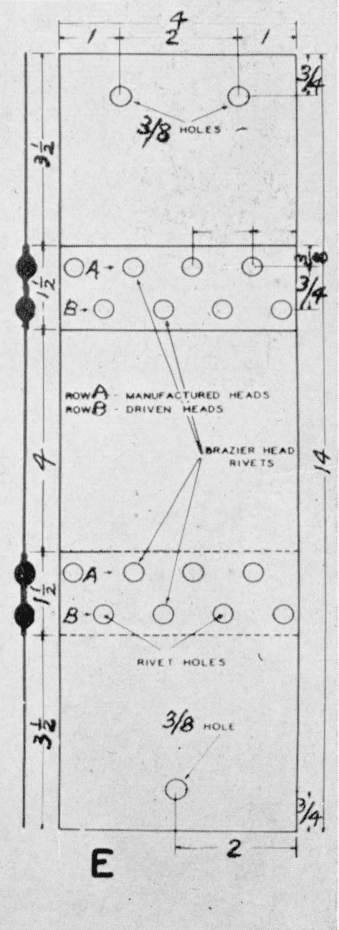

FiguRE 1.-Types and dimensions of specimens.

$A$ and $B$, tensile bars; $C$ and $D$, strips; $E$, panel used in the current exposure program, superseding previous types. Circles on specimen $D$ indicate spot welds or rivets. 

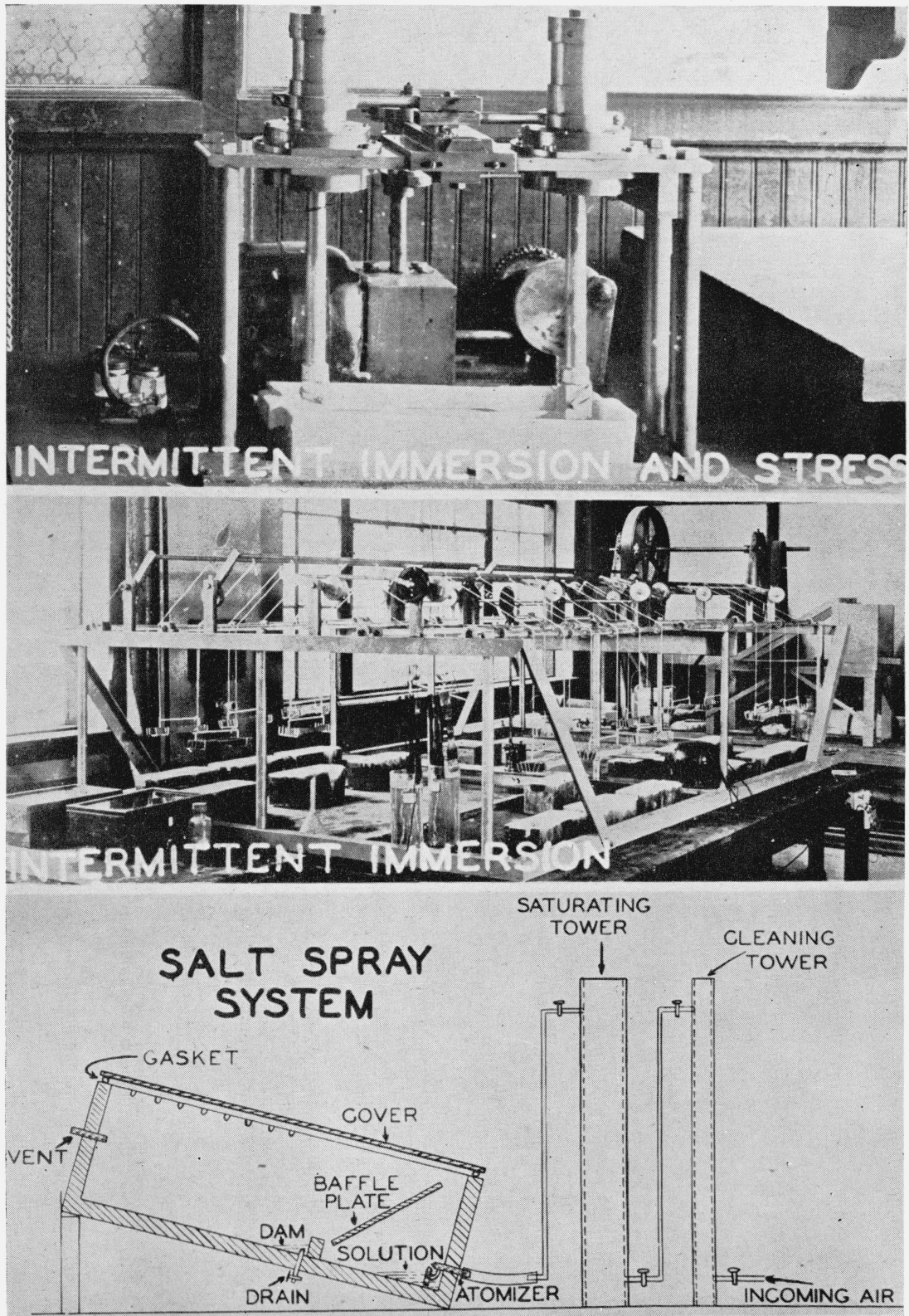

FiguRe 2.-Apparatus used in the laboratory corrosion tests. 

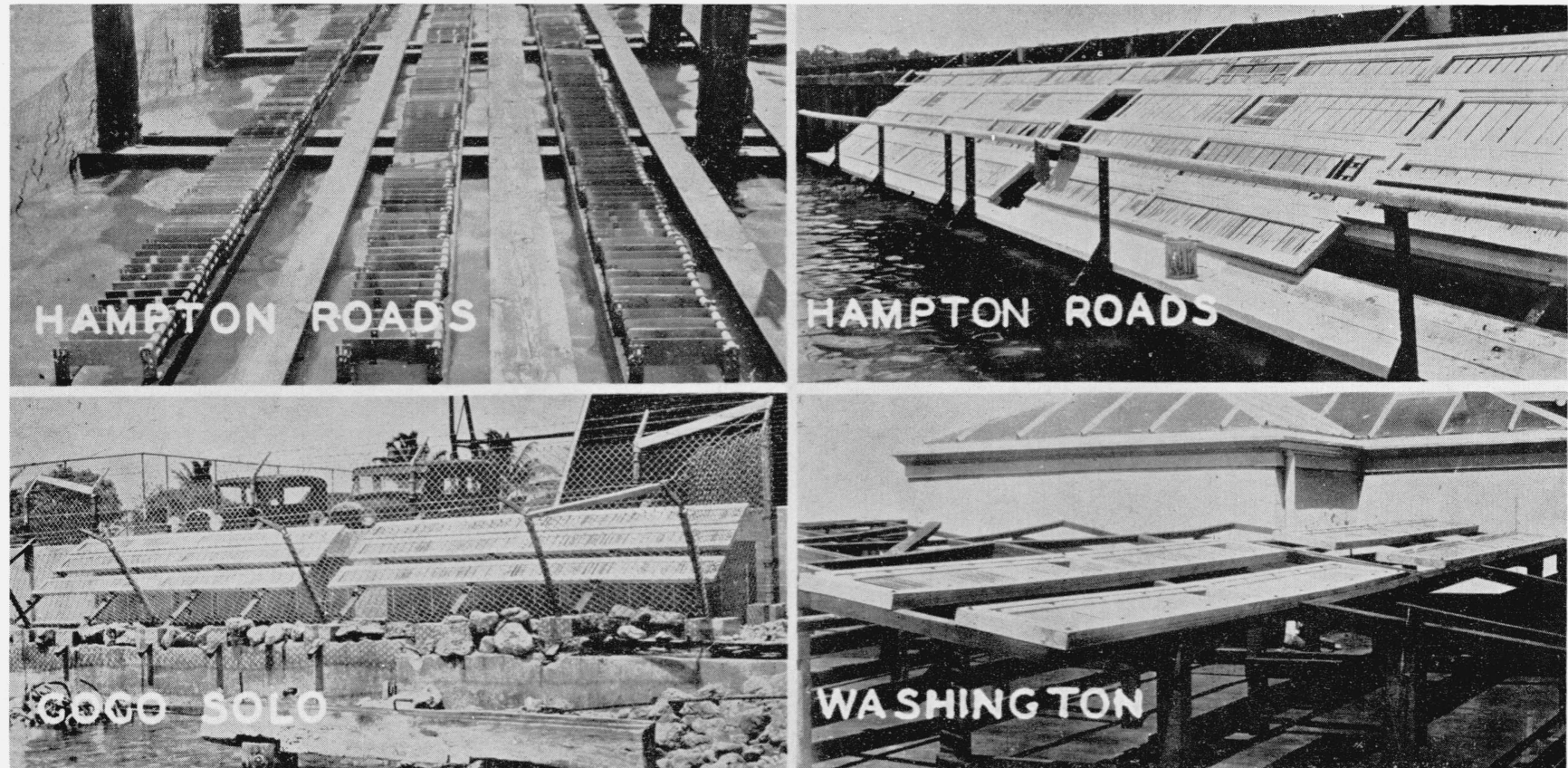

FIgURE 3.-Weather-exposure, and tidewater (upper left) installations. 


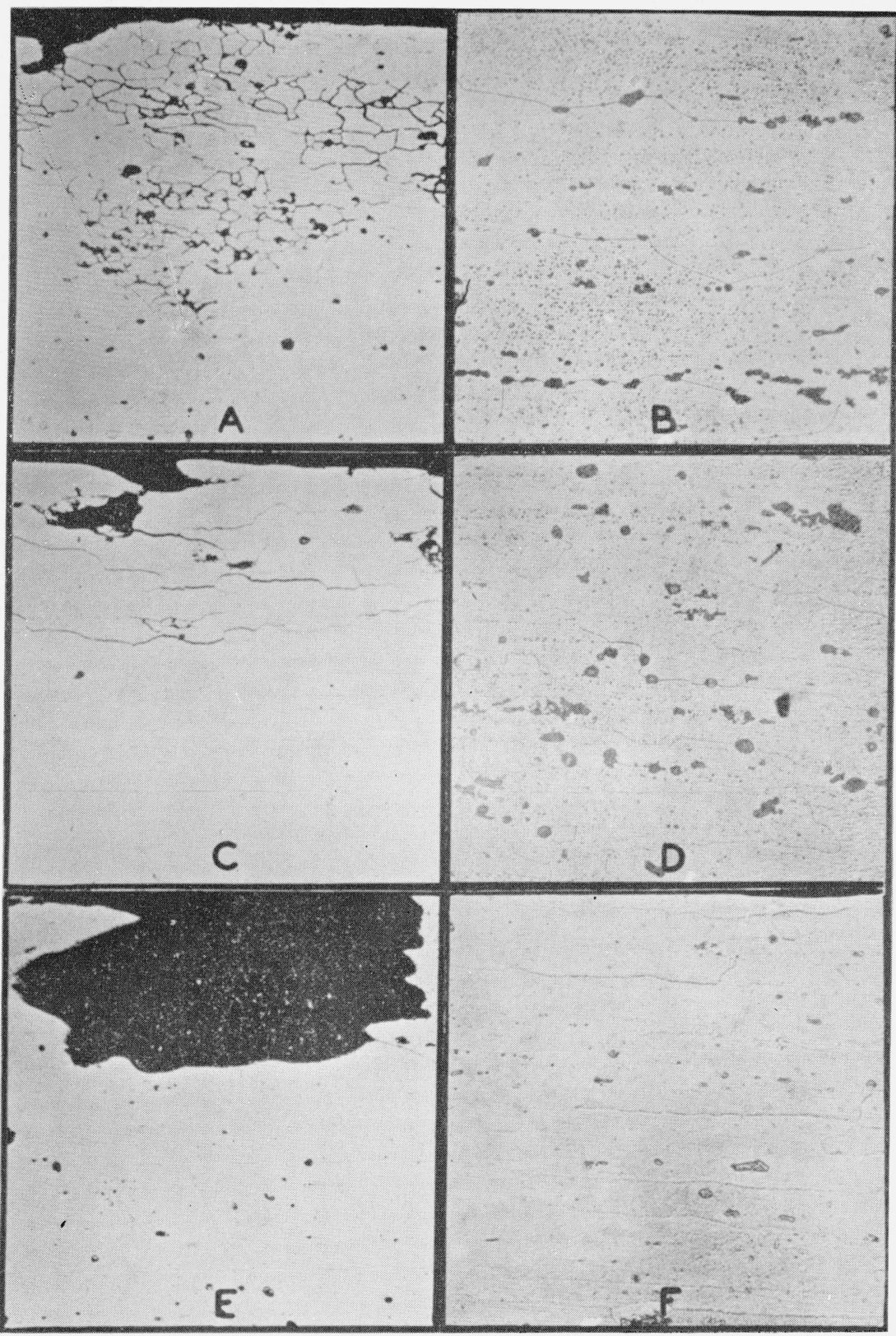

FIGURE 4.-Cross sections of characteristic types of corrosive attack found in duralumin, and the microstructures associated with each.

$A$, Intercrystalline attack; $C$, intercrystalline "pock-form" corrosion; $E$, pitting attack. Etching reveals much precipitation of $\mathrm{CuAl}_{2}$ particles within the grains and along the boundaries in specimens, $B$ and $D$, that are susceptible to intererystalline attack. These particles are retained in solid solution in $F$. $\times 2 C 0$. 


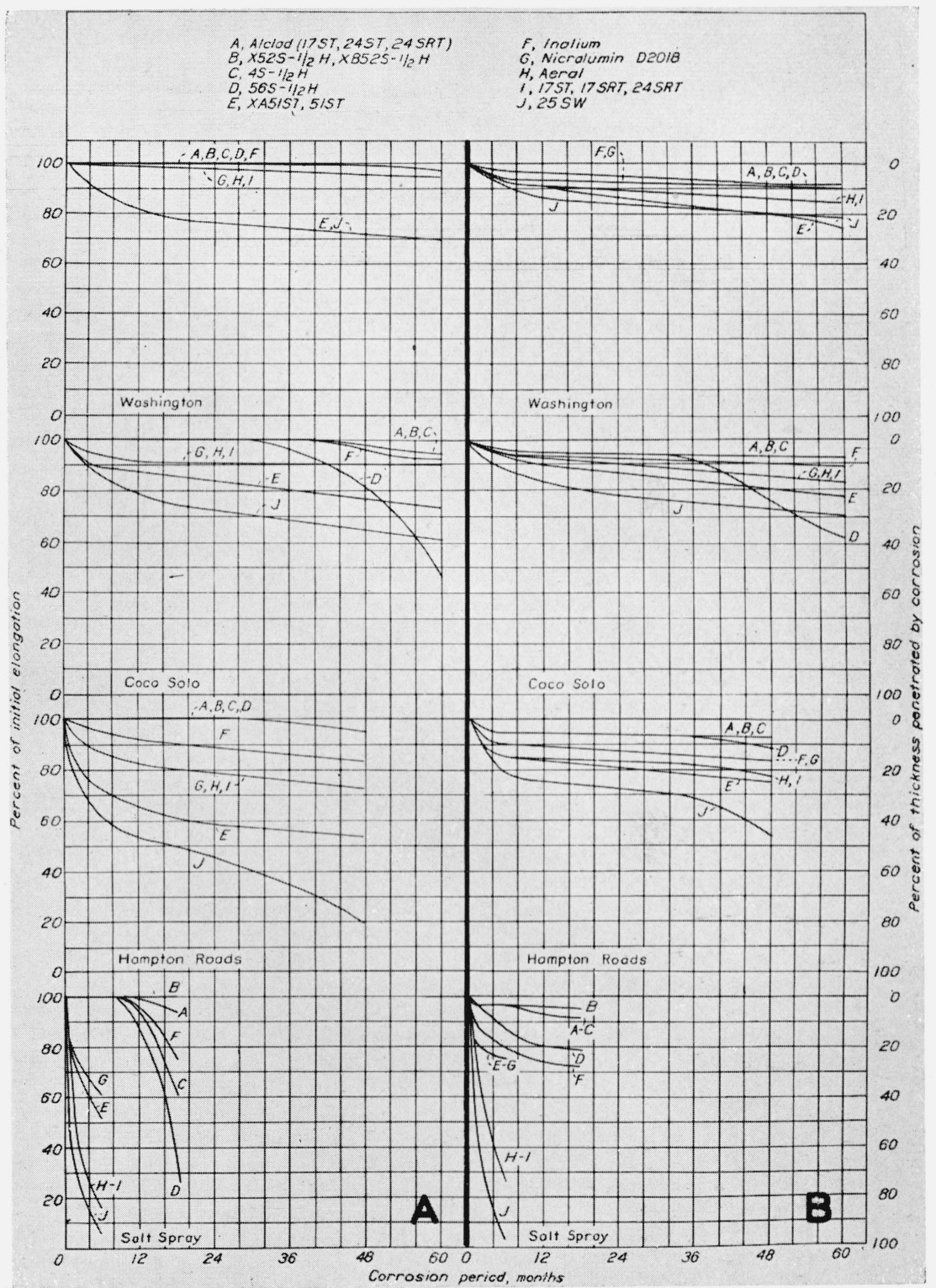

FIgURE 5.- Rates of loss in ductility, $A$, and of penetration of corrosive attack, $B$, for the various aluminum alloys at each exposure locality. 


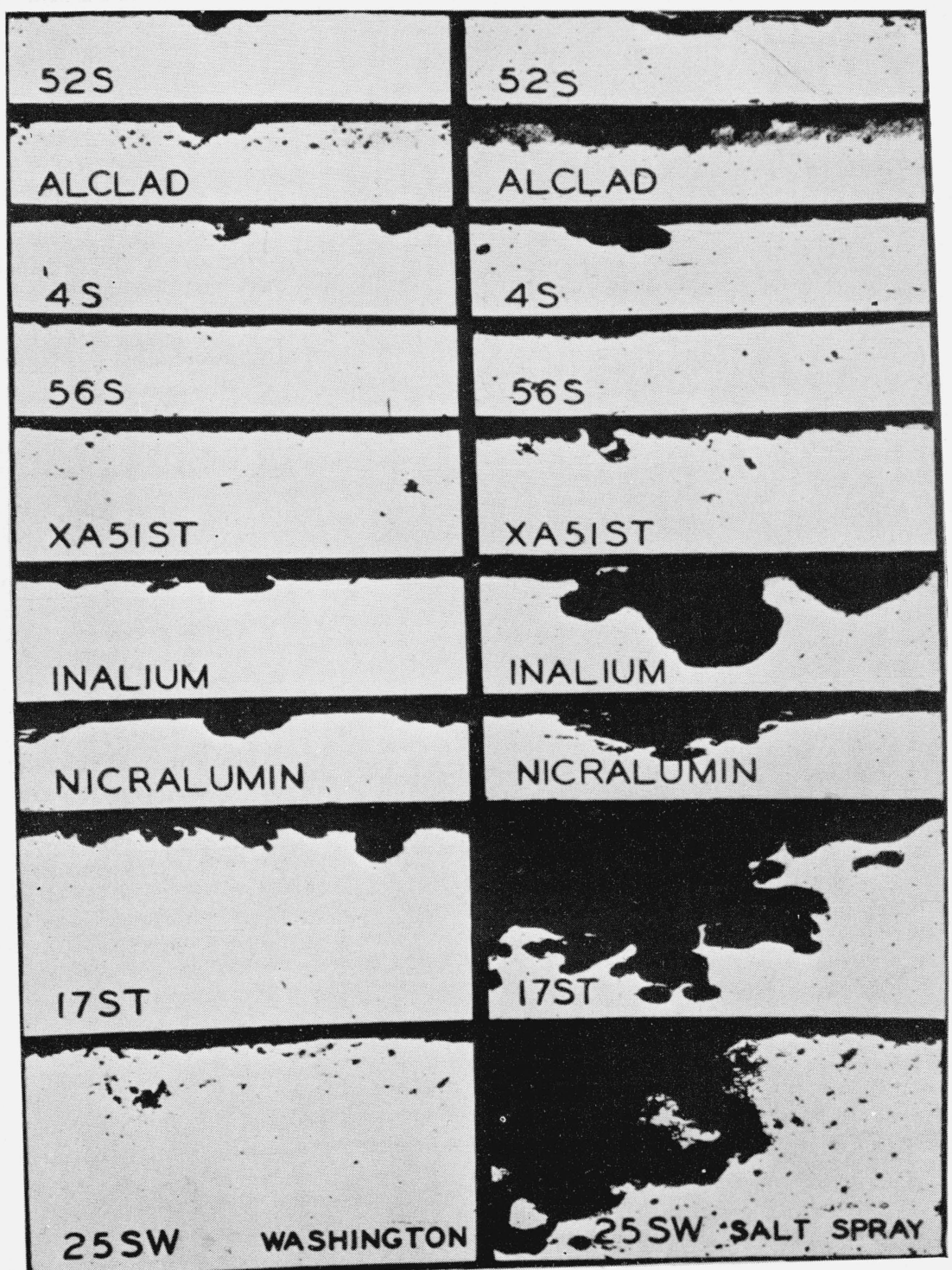

FIGURE 6.-Representative cross sections of the maximum penetration of corrosive attack on sheets exposed 5 years at Washington (left column) and in the laboratory salt-spray tests (right column).

Talt-spray tests

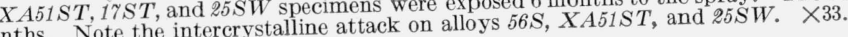




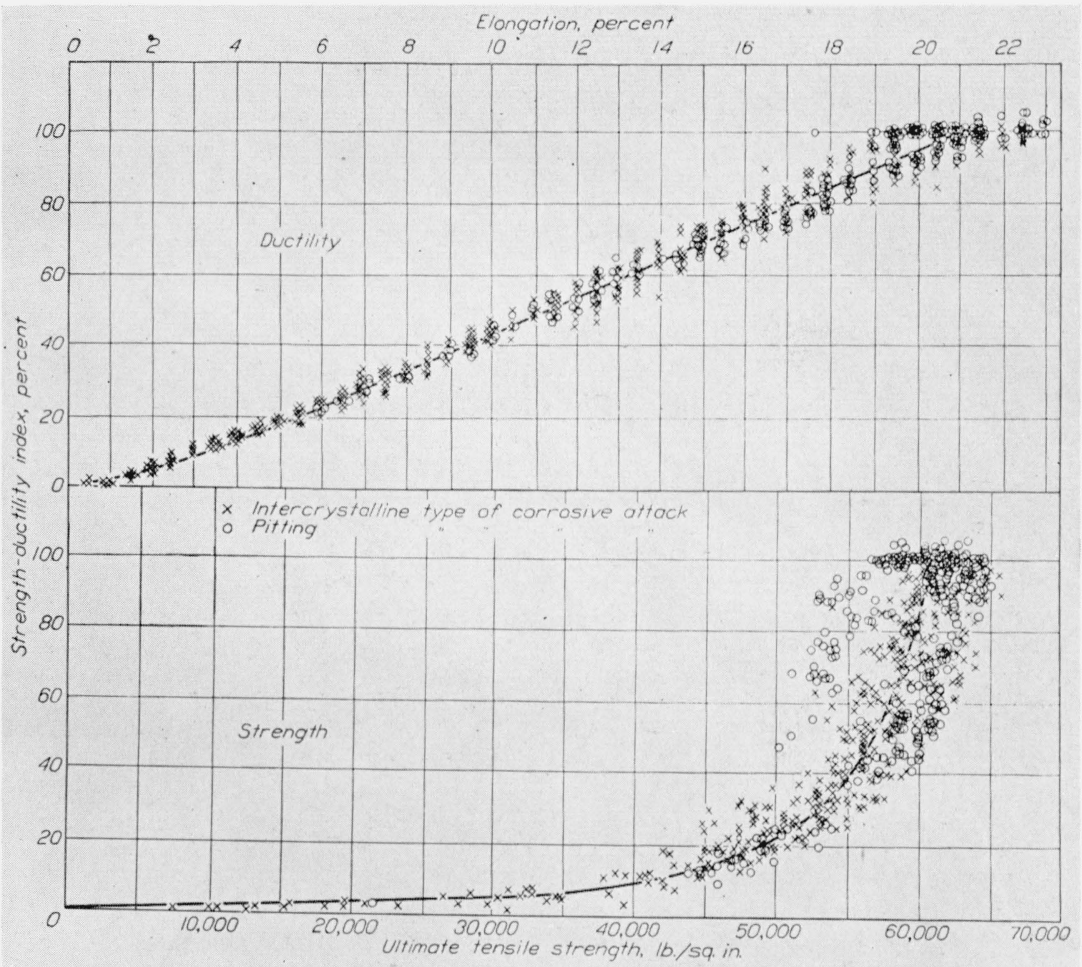

FIGURE 7.-Relation of physical properties of heat-treated duralumin specimens exposed to the weather.

The strength-ductility index represents the ratio, on a percentage basis, of the product of the tensile strength and elongation of the corroded specimen to the corresponding average product for the uncorroded specimens. The changes in strength relative to ductility show that the latter is a better measure of corrosion on this alloy, although neither is accurate during the initial stages of attack. 


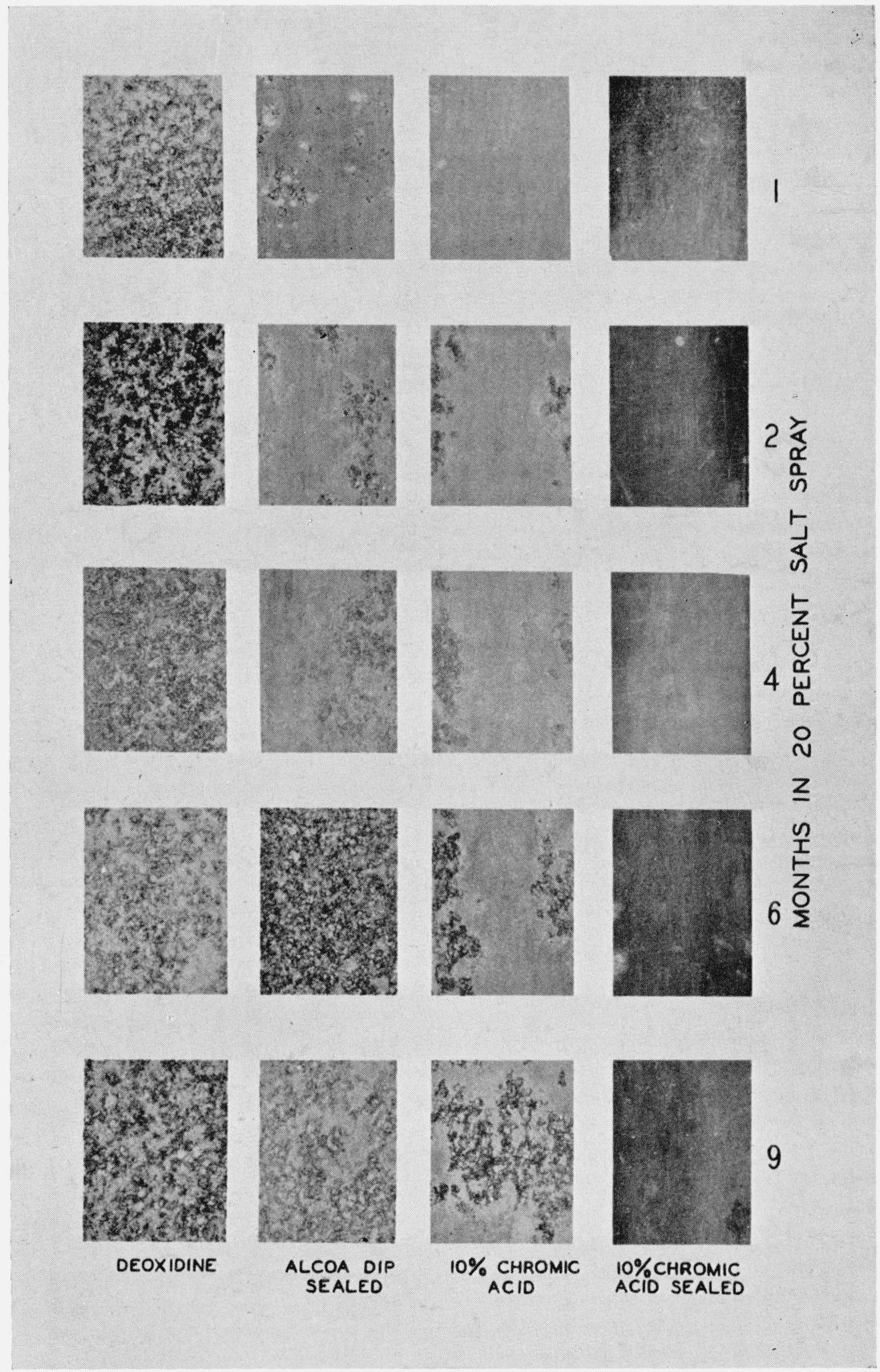

Figure 8.- Surface appearance, showing relative efficiencies of some oxide coatings applied to $17 S$ specimens that were exposed to the laboratory salt-spray test for the periods indicated.

Note the marked superiority of the anodic coating, especially when given a sealing treatment. $\times 1$. 

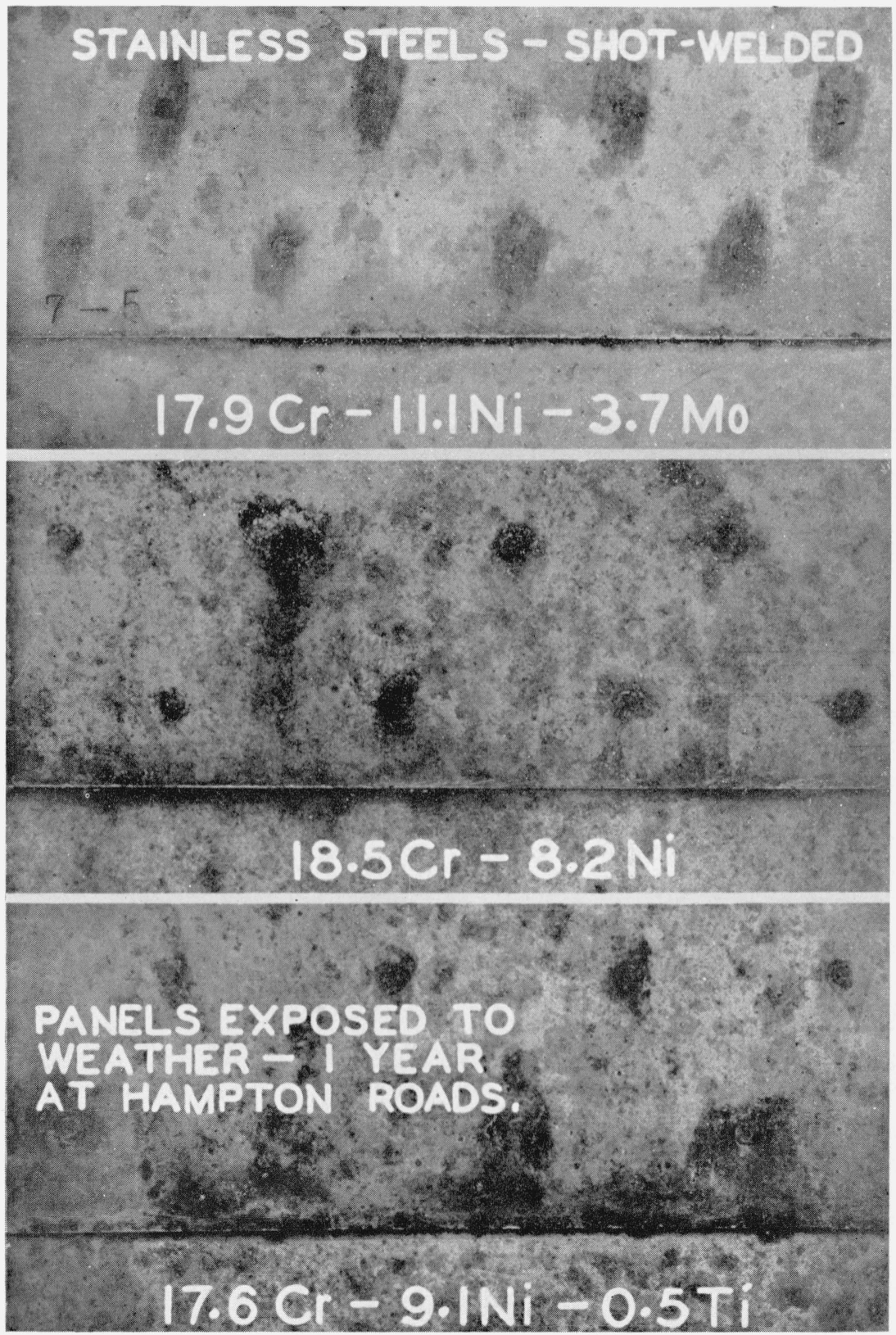

Figure 9.-Stainless steel panels exposed to the weather.

Steels containing molybdenum rusted much less readily than the others tested. $\times 1$. 
Journal of Research of the National Bureau of Standards

Research Paper 1316
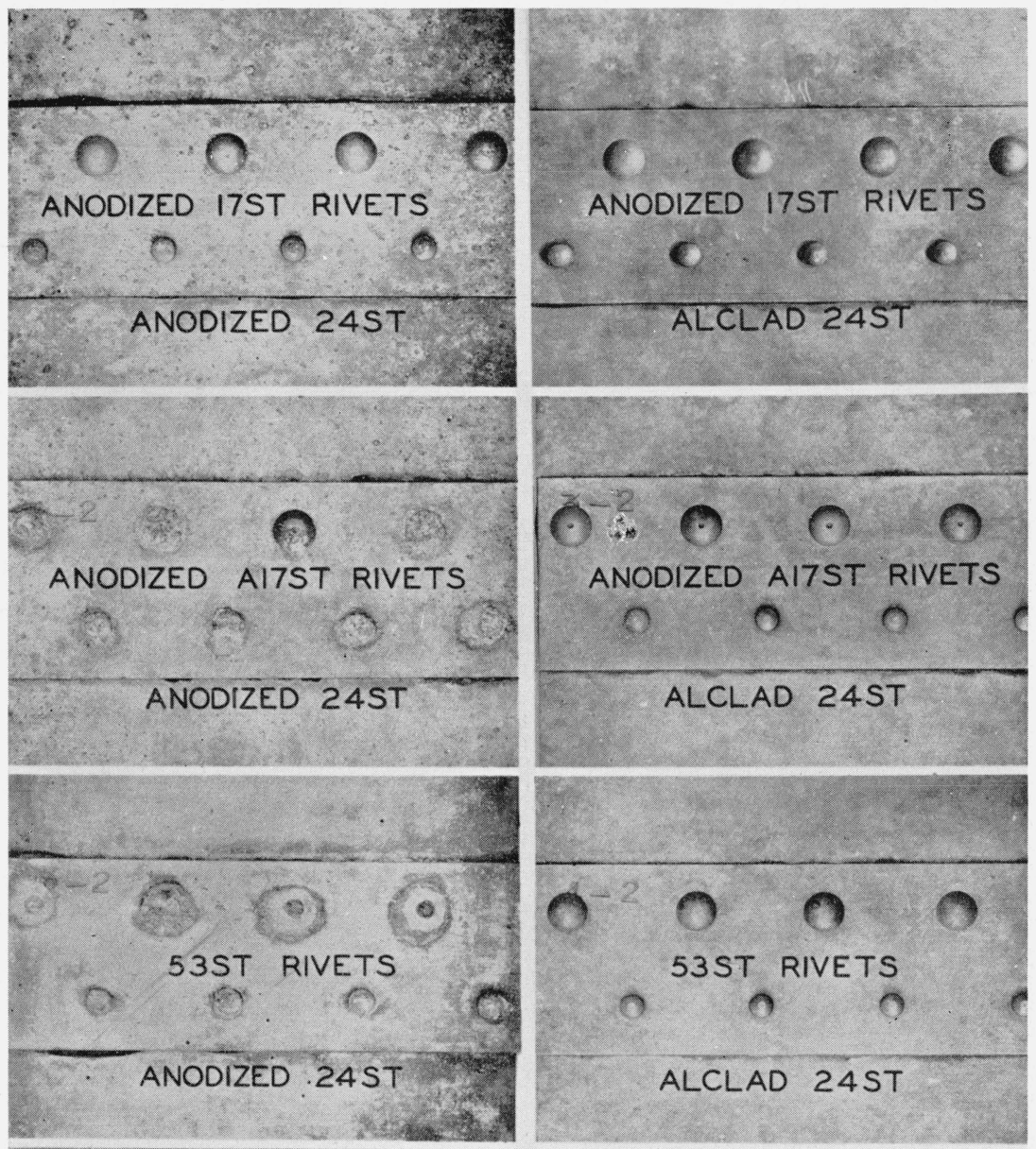

PANELS EXPOSED TO TIDE-WATER - I YEAR AT HAMPTON ROADS.

AM55S RIVETS

ANODIZED DOWMETAL M
STRIPS SAME ALLOY AS REST OF PANEL.

SST RIVETS

ANODIZED DOWMETAL M

Figure 10. -Corrosion on rivets used for joining on panel sections of aluminumand magnesium-rich alloys exposed to tidewater. $\quad \times 1 / 2$. 

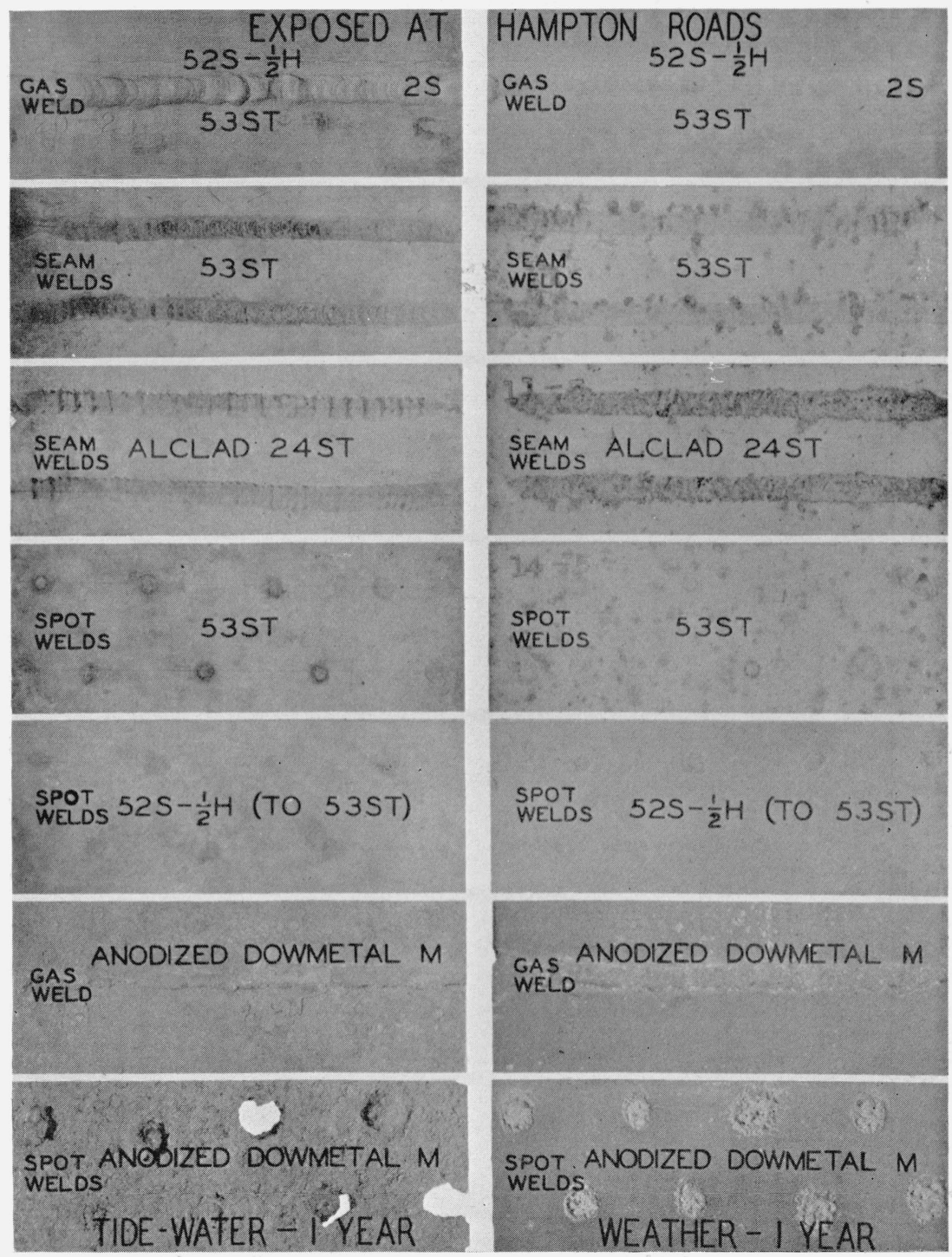

Figure 11.-Corrosion on welds used for joiring aluminum-and magnesium-rich alloys exposed to tidewater. $\times 1 / 2$. 


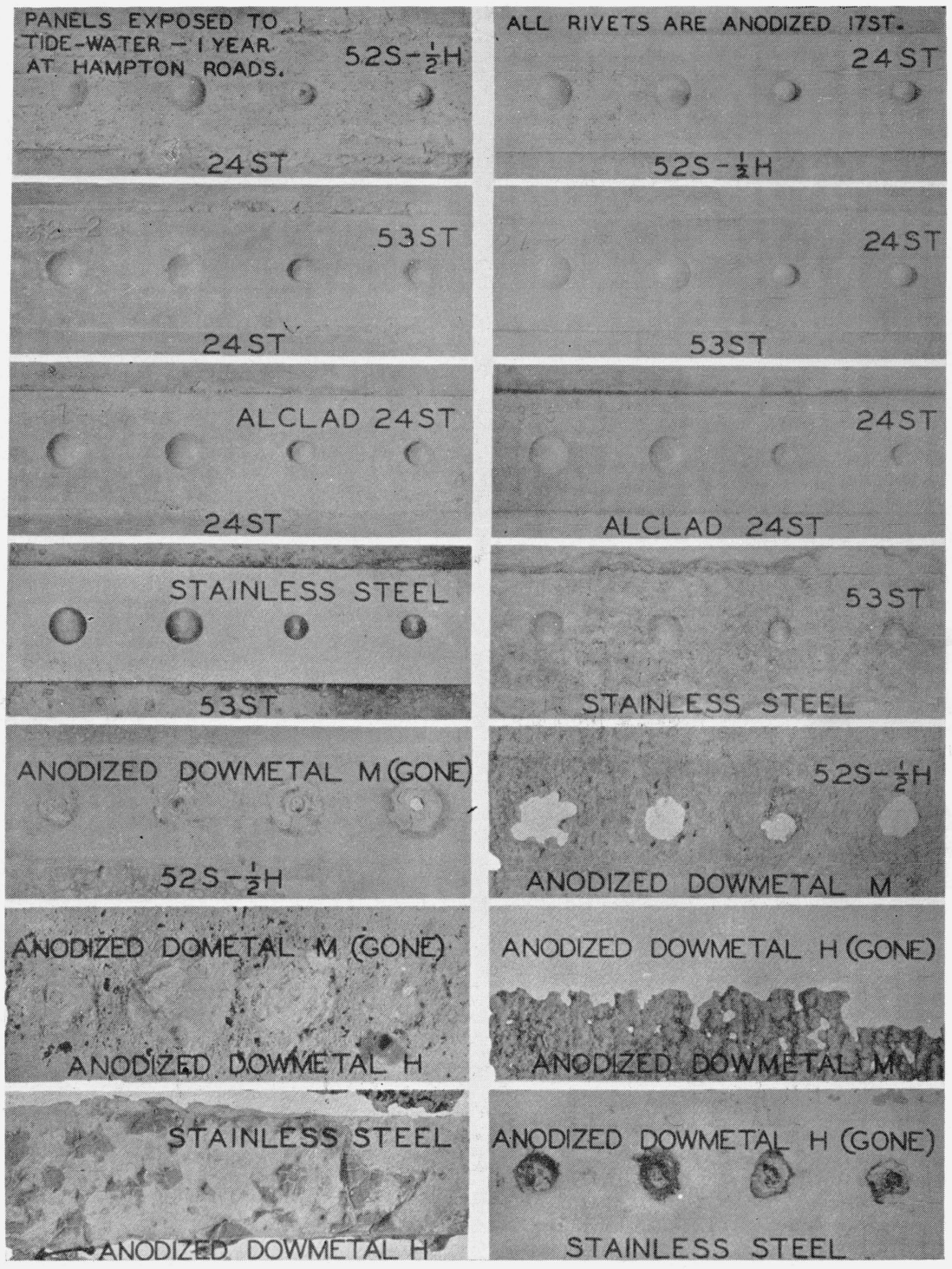

FIGURE 12.-Corrosion on panels having dissimilar metals in contact and exposed to tidewater. $\times 1 / 2$. 
in solid solution. This eliminated intercrystalline corrosive attack. Reheating above $100^{\circ} \mathrm{C}$ of properly quenched-and-aged material also caused precipitation of the $\mathrm{CuAl}_{2}$ compound and so promoted intercrystalline corrosion. Specifications now require proper heat treatments, which eliminate the intercrystalline attack.

An effort was next made to minimize the pitting type of attack. The results indicated that this could be accomplished by preparing alloys from high-purity components and, where possible, by using alloys of slightly lower strength, in which the iron and copper contents are low. Private industry, in line with these findings, developed a series of aluminum-rich alloys that contain from 1 to 6 percent of magnesium and no copper, and that proved to be extremely resistant to corrosion. Certain of these alloys have exhibited only a slight loss in tensile properties after 1 year in the salt-spray test or after 5 years' exposure to the weather at the marine localities. The rates of corrosion of a number of aluminum alloys are shown in figure 5, and figure 6 reveals the typical appearance of cross sections of corroded samples under the microscope.

Owing to the large number of specimens tested, it was possible to obtain fundamental data upon changes in physical properties that resulted from corrosion, irrespective of both time and conditions of exposure. These relations and the amount of "scatter" in results are shown in figure 7 for a duralumin alloy, $17 \mathrm{ST}$.

\section{PROTECTIVE COATINGS ON ALUMINUM ALLOYS}

The advisability of applying protective coatings to duralumin to be used under marine conditions was early demonstrated. Metal-. sprayed coatings of high-purity aluminum were found to be very efficient in protecting the duralumin basis metal. Private industry subsequently developed materials, known as "Alclad", which consist of a duralumin basis, to which a coating of aluminum is integrally bonded through interalloying. The tests (figs. 5 and 6 ) have demonstrated the superior corrosion resistance of these materials, which have proved of immense value to the aircraft industry.

Oxide films, applied to aluminum alloys by means of chemical or electrochemical (anodic) treatments, are of particular value, because they greatly improve the adherence of paints and varnishes applied on such surfaces. Many methods of surface protection were systematically investigated. Specimens bearing various oxide films were used in weather-exposure tests with and without an aluminumpigmented varnish of known quality. This and various other paint and varnish coatings were applied to specimens that had received no surface treatment and to duplicates oxidized by an anodic treatment. The tests disclosed that, in general, anodic coatings were more efficient than those applied by simple immersion methods. Anodic films "sealed" by heating in dichromate solutions or by permitting chromic acid to dry on their surfaces were found to be very corrosion-resistant (fig. 8). Such coatings, used in conjunction with good grades of aluminum-pigmented varnishes, proved satisfactory for use under relatively severe corrosive conditions for periods in excess of 3 years.

An excellent method of anodic treatment for aluminum alloys, developed at this Bureau, consists in anodizing at 40 volts in a 10 -percent 
chromic-acid bath at $35^{\circ} \mathrm{C}$ for $1 / 2$ to 1 hour. This method, and another one developed at the Bureau for anodically treating magnesium-rich alloys, have been included in Government specifications.

\section{CORROSION OF MAGNESIUM ALLOYS}

Since intercrystalline corrosion does not occur in magnesium-rich alloys, the main objective has been to determine which compositions (table 2) are most resistant to corrosive attack and to discover adequate means for surface protection. Alloys of essentially the binary type, containing from 4 to 10 percent of aluminum, were shown to be increasingly susceptible to corrosive attack as their contents of aluminum were increased. The addition of zinc to magnesiumaluminum alloys somewhat improved their corrosion resistance, and additions of from 4 to 6 percent of tin proved very beneficial. The latter and a binary magnesium-manganese alloy were the most corrosion-resistant magnesium alloys tested. Because of improvements in the purity of the constituent metals, the corrosion resistance of all the magnesium alloys has been improved markedly within the past decade.

\section{PROTECTIVE COATINGS ON MAGNESIUM ALLOYS}

The surface coatings for magnesium alloys so far developed are not so protective as are the anodic coatings on aluminum alloys, but they serve a useful purpose by improving the adherence of paints. In this respect some coatings obtained by simple immersion methods have proved as efficient as anodic coatings. If dimensional changes must be avoided, however, the latter treatment is recommended. The anodic treatment developed at the National Bureau of Standards for magnesium alloys uses an aqueous solution containing 10 percent by weight of sodium dichromate and 2 percent of monobasic sodium phosphate. The bath should be operated at a pH of $4.5 \pm 0.2$. Articles are treated for 45 minutes at $50^{\circ} \mathrm{C}$ and at a current density of from 2 to 10 amperes per square foot, depending upon the alloy. Good grades of aluminumpigmented paint, used in conjunction with satisfactory surface treatments, have adequately protected the more corrosion-resistant magnesium alloys during 5 years of exposure to the weather at the marine localities, and for 1 year in the tidewater racks.

\section{CORROSION OF STAINLESS STEELS}

All the stainless steels investigated (table 3) were in the form of polished cold-rolled sheets, 0.018 inch thick, with surfaces passivated by immersion for approximately 1 hour in 20-percent nitric acid at $60^{\circ}$ C. Panels exposed to the weather became covered more or less uniformly with thin, but adherent, rust films (fig. 9). The rust formed during the first month, and accumulations of dust and soot may have been partly responsible. However, corrosive attack on the panels exposed to tidewater was slight and was confined to a few small localized areas. Alloys that contained molybdenum proved more resistant to attack than did those with additions of titanium or columbium, or than those without any added alloying elements. An alloy containing 16 percent of chromium and 1 percent of nickel was much more susceptible to corrosion than the others. 


\section{CORROSION OF RIVETS AND WELDS}

In the current program, which has been in progress approximately 2 years, panels are being exposed to the weather and to tidewater at Hampton Roads only. The tidewater tests have proved especially valuable for rapidly determining the behavior of different alloys in contact with each other and the best methods for joining them. For example, anodized 17ST rivets (fig. 10) proved best for joining anodized 24ST sheets, but other rivets were equally satisfactory for joining other alloys. AM55S rivets, which contain approximately 95.4 percent of aluminum and 4.5 percent of magnesium, were far superior to other rivets for joining magnesium alloys. On both the aluminum-rich and magnesium-rich alloys, gas welds were very resistant to corrosion (fig. 11). Spot welds were somewhat more susceptible to attack, while seam welds were noticeably so. Shot welds on stainless steel (fig. 9) tended to acquire greater deposits of rust than did the remainder of the panel. Although no visible evidence was obtained of the presence of deep pits on the welds, it is planned to verify this condition by means of flexural fatigue tests. Preliminary tests of this type on unwelded portions of the panels have indicated that shallow pits are present. Somewhat lower fatigue limits were obtained on panels exposed to the weather than on those exposed to tidewater for equal periods.

\section{CORROSION OF DISSIMILAR METALS IN CONTACT}

The frequent necessity, in aircraft construction, of making contacts between dissimilar metals shows the importance of the electrolytic effects involved. In order to obtain basic information, no insulating materials were used at the faying surfaces, and the panels were not painted. The ratio of the areas of the dissimilar metals very often proved a determining factor in the resulting corrosion. For example, a strip of 52S-1/2H aluminum alloy, 1 inch wide, joined to a main panel of $24 S T$ alloy was severely pitted (fig. 12); whereas with the relative areas reversed, the corrosion was much less severe. Aluminum and aluminum-magnesium alloys were anodic to alloys of the duralumin type and were attacked when in contact with them. The corrosion resulting from a few other contacts of dissimilar metals is shown in figure 12. More detailed information on these and on most of the features discussed in the present paper is available in the literature references which follow.

It may be possible to minimize, or eliminate, the corrosion of dissimilar metals in contact by inserting appropriate insulators between their faying surfaces. Some preliminary studies have been included in the current exposure program, and more detailed research upon insulators for this purpose is planned.

\section{REFERENCES}

[1] H. S. Rawdon, A. I. Krynitsky, and J. F. T. Berliner, Brittleness developed in aluminum and duralumin by stress and corrosion, Chem. Met. Eng. 26, 154 (1922).

[2] H. S. Rawdon, The intercrystalline corrosion of metals, Ind. Eng. Chem. 19, 613 (1927); Met. Ind. (London) 30, 647 (1927).

[3] H. S. Rawdon, Protection of duralumin against corrosion, Brass World 24, 147 (1928). 
[4] H. S. Rawdon, Duralumin for airplane use, Mining and Met. 9, 234 (1928).

[5] H. S. Rawdon, Corrosion Embrittlement of Duralumin, I. Practical Aspects of the Problem, NACA Tech. Note 282 (1928). II. Accelerated Corrosion Tests and the Behavior of High-Strength Aluminum Alloys of Different Compositions, NACA Tech. Note 283 (1928). III. Effect of the Previous Treatment of Sheet Material on the Susceptibility to This Type of Corrosion, NACA Tech. Note 284 (1928). IV. The Use of Protective Coatings, NACA Tech. Note 285 (1928). V. Results of WeatherExposure Tests, NACA Tech. Note 304 (1929). VI. The Effect of Corrosion, Accompanied by Stress, on the Tensile Properties of Sheet Duralumin, NACA Tech. Note 305 (1929); Proc. Am. Soc. Testing Materials 29, pt. 2, 314 (1929).

[6] H. S. Rawdon, Correlation of laboratory corrosion tests with service: Weatherexposure tests of sheet duralumin, Trans. Am. Inst. Mining Met. Engrs., Inst. Metals Div., p. 220 (1929).

[7] H. S. Rawdon, Corrosion prevention methods as applied in aircraft construction, Proc. Am. Soc. Testing Materials 30, pt. 2, 61 (1930); Aviation Eng. 3, $23(1930)$.

[8] R. W. Buzzard and W. H. Mutchler, Advantages of Oxide Films as Bases for Aluminum Pigmented Surface Coatings for Aluminum Alloys, NACA Tech. Note 400 (1931).

[9] W. H. Mutchler, Surface coatings for aluminum alloys, Metals \& Alloys, 2, $324(1931)$

[10] W. H. Mutchler, The Weathering of Aluminum Alloy Sheet Materials Used in Aircraft, NACA Tech. Report 490 (1934).

[11] W. H. Mutchler, Weather-Exposure Tests on Magnesium Alloys, Confidential report to NACA (available only to Federal Departments) (Aug. 20, 1935).

[12] R. W. Buzzard and J. H. Wilson, Deterioration of chromic acid baths used for anodic oxidation, J. Research NBS 18, 53 (1937) RP961.

[13] R. W. Buzzard and J. H. Wilson, Anodic coating of magnesium alloys, J. Research NBS 18, 83 (1937) RP964.

[14] R. W. Buzzard, Anodizing of aluminum alloys in chromic acid solutions of different concentrations, J. Research NBS 18, 251 (1937) RP975.

[15] W. H. Mutchler and H. O. Willier, A note on rapid photomicrography, Trans. Am. Soc. Metals 26, pt. 1, 279 (1938).

[16] W. H. Mutchler, R. W. Buzzard, and P. W. C. Strausser, Salt Spray Test, Letter Cir. NBS 530 (1938).

[17] W. H. Mutchler, The Effect of Continuous Weathering on Light Metals Used in Aircraft, NACA Tech. Report 663 (1939).

[18] W. H. Mutchler and W. G. Galvin, Tidewater and Weather-Exposure Tests on Metals Used in Aircraft, NACA Tech. Note 736 (1939).

Washington, April 23, 1940. 